\title{
Advances in Biogenic Nanoparticles and the Mechanisms of Antimicrobial Effects
}

\author{
AFIFA QIDWAI, A. PANDEY, R. KUMAR, S. K. SHUKLA AND A. DIKSHIT* \\ Biological Product Laboratory, Botany Department, University of Allahabad, Allahabad-211 002, India
}

Qidwai, et al.: Biogenic Advances in Nanoparticles

\begin{abstract}
Innovations in the nanotechnological arena have paved a path leading to nano-revolution, which has most recently unfurled the role of plants in the biogenic synthesis of nanoparticles. Though synthesis of nanoparticles can be accomplished through physical and chemical techniques, biological course of synthesis has proficiently proved competent over other techniques. The problem of evolving multidrug resistant bacteria, due to irrational use of antibiotics, makes the biogenically synthesized nanoparticles attractive, due to their promising efficacy with negligible side effects. Consequently, the nanoparticles becoming better substitutes for conventional treatment besides overcoming all the limitations. Nanoparticles have great stability and potent antibacterial activity. The uniqueness lies in their size $(10$ and $500 \mathrm{~nm})$ and dimension offers these particles to dynamically communicate with biomolecules on the cell surfaces and within the cells, so proficiently to decode and designate various biochemical and physiochemical properties of the cells. The present review aims to recapitulate various emerging efforts in the biogenic synthesis of nanoparticles, most significantly their unique mechanisms of action with different approaches as well as the factors that may add up to their antimicrobial activity.
\end{abstract}

Key words: Antibacterial, biocidal, biogenic, multidrug resistant, nanoparticles

In recent years, the ever-escalating use of high dosage of antibiotics has created the trauma of multidrug resistant (MDR) strains, particularly bacterial pathogens, thereby substantially mitigating the effect of concerned antibiotics. The reduced effectiveness of drugs testifies MDR bacteria could be a major threat to human health ${ }^{[1]}$. Therefore, the need to come up with a more effective and non-toxic treatment arose, which was followed by the advances in biotechnology pioneered the domain of nanotechnology. Nanomaterials (NM) are of great interest due to their novel physicochemical, magnetic and optoelectronic properties that are administered (metal NM are preferred topical administration route, while others like polymeric NM are administrated via oral as well as topical route) by their unique size, shape, and distribution (Table 1$)^{[2,3]}$.

"Nanotechnology is the application of science to control matter up to the molecular level"[4], and is currently one of the most active areas of research. Nanoparticles (NPs) are generally recognized as materials having at least one dimension between 1$100 \mathrm{~nm}^{[5,6]}$. It is considered as a transitional zone between individual molecules and the analogous bulk materials, which enable it to hold unique properties, which are peculiar from their molecular and bulk analogue ${ }^{[7,8]}$. There are many sources of NP synthesis, but the green approaches are gaining popularity. Plant parts such as, the leaf, the bark, the flower, the peel, and the seed and microorganisms such as fungi, bacteria, algae, yeast, actinomycetes, and enzymes offer clean, eco-friendly, non-toxic machinery for their synthesis, which is compatible with pharmaceutical and cosmeceutical applications $^{[9-11]}$. These NMs have long been documented to exhibit microbiocidal, microbiostatic actions and serve as potential antibacterial agents in medical and industrial applications ${ }^{[12]}$. The highly reactive metal or metal oxide NP show bactericidal activity against both Gram-positive and Gram-negative bacteria $^{[13]}$. The NPs have been known for targeted drug delivery; hence check specific microorganism growth. These properties have broadened their application

This is an open access article distributed under the terms of the Creative Commons Attribution-NonCommercial-ShareAlike 3.0 License, which allows others to remix, tweak, and build upon the work non-commercially, as long as the author is credited and the new creations are licensed under the identical terms

Accepted 10 May 2018

Revised 22 May 2017

Received 30 November 2016

Indian J Pharm Sci 2018;80(4):592-603 
to the genomics, biosensors, clinical chemistry and immune response enhancement ${ }^{[14]}$. This review aims to describe various approaches intended for biogenic synthesis of metal or metal oxide NPs, and to elaborate extracellular and intracellular biocidal mechanisms of these particles along with the factors that might influence the activity of NPs.

\section{SYNTHESIS OF NPS}

Various processes for the synthesis of NPs have been employed up to recently, mainly in the chemical, physical and biological field, but their fabrication was found to be expensive and the involvement of toxic chemicals for their synthesis makes the way for biological synthesis as a more preferred option. In biogenesis, bacterial, fungal and plant extract sources can be used for their synthesis; this type of fabrication is very reliable, cost effective and nontoxic ${ }^{[15]}$. Among all the preferred methods suggested for nanoparticle synthesis; the chemical reduction method and biological synthesis method were widely considered due to its advantage in controlling particle size and morphology very commendable. The comparative difference between chemically and biogenically synthesized NPs is shown in Table $1^{[15-17]}$.

The two most commonly employed processes of NP synthesis involves the top down and bottom up pathway. In top-down pathway, the bulk materials are broken down to small particles of nanoscale by many lithographic methods like mechanical milling/ ball milling, and chemical etching. This approach introduces imperfections in the surface structure of the product, which become the major limitation since physical properties and surface chemistry of NPs are highly dependent on the surface structure ${ }^{[17]}$. In the bottom up pathway, the NPs are prepared from smaller strating materials through oxidation and bioreduction procedures (fig. 1). Atoms aggregate to form nuclei range at nanoscale, thus the NPs obtained are with negligible flaws. The biological procedure involves capping and stabilizing mediators (phytochemicals like phenolics, flavonoids, terpenoids, and cofactors) that contribute higher stability ${ }^{[17,18]}$ (fig. 2). Apart from this, advanced studies reflected the succeeding role of microorganisms in green synthesis because of the ease of process involved in the synthesis, much stable NPs and cost effectiveness ${ }^{[19,20]}$. The biogenic synthesis uses varied life forms, starting from the very simple prokaryotic bacterial cells to composite eukaryotes such as angiosperms ${ }^{[21]}$. Various green sources employed for biogenic synthesis and their impact is summarized below.

\section{Bacterium-mediated green synthesis:}

The ability of bacteria to produce inorganic intracellular and extracellular materials makes them prospective biofermenters for the synthesis of gold and silver NPs (AgNPs). Silver is well-known for its biocidal activity, however, there are bacteria that are resistant to silver ${ }^{[22]}$ and can facilitate the cell to accumulate silver on its cell wall up to $25 \%$ of their dry weight biomass. Therefore, initiating the role of these bacteria (Table 2) in industries for the recovery of silver from ores ${ }^{[23]}$. Pseudomonas stutzeri AG259 (first silver resistant bacteria) was used for the synthesis of noble NPs. Bacteria cultured in high concentration of silver nitrate can accumulate silver in large bulk (with nanoscale $200 \mathrm{~nm}$ diameter) ${ }^{[24]}$. Proteus mirabilis PTCC 1710 found even more proficient for NPs synthesis ${ }^{[25]}$. Further, it was reported that during incubation of bacteria the type of broth (nutrient broth, Muller-Hinton broth) used may promote synthesis of NPs (extracellular or intracellular). Therefore, selected and controlled incubation creates bacteria-based

TABLE 1: COMPARATIVE DIFFERENCES BETWEEN BIOGENIC AND CHEMICALLY SYNTHESIZED NANOPARTICLES ${ }^{[5,9,11,13,15-17]}$

\begin{tabular}{|c|c|c|}
\hline Properties & Chemical & Biological \\
\hline Nature & Expensive, toxic & Cost effective, nontoxic \\
\hline Reducing agent & $\begin{array}{c}\text { Dimethylformamide, ethylene glycol, hydrazine } \\
\text { hydrate, sodium borohydride, polyol, sodium } \\
\text { citrate and N,N-dimethyformamide }\end{array}$ & $\begin{array}{l}\text { Biomolecules include phenolics, polysaccharides, } \\
\text { flavones, terpenoids, alkaloids, proteins, amino } \\
\text { acids, enzymes, predominantly, nitrate reductase }\end{array}$ \\
\hline Method & $\begin{array}{l}\text { Stabiliser (surfactant) is added to the first solution } \\
\text { to prevent the agglomeration of nanoparticles }\end{array}$ & There is no need to add a stabilising agent \\
\hline $\begin{array}{l}\text { Environmental } \\
\text { impact }\end{array}$ & $\begin{array}{l}\text { Environmental pollution is a disadvantage of the } \\
\text { chemical method and the chemical reduction } \\
\text { methods are energy-intensive }\end{array}$ & $\begin{array}{l}\text { Synthesis carried out in environmental conditions } \\
\text { and they are safe enough, and consume no energy }\end{array}$ \\
\hline $\begin{array}{l}\text { Antibacterial } \\
\text { activity }\end{array}$ & $\begin{array}{c}\text { The chemically synthesized nanoparticles showing } \\
\text { comparatively lower antimicrobial activity against } \\
\text { pathogenic bacteria }\end{array}$ & $\begin{array}{c}\text { The nanoparticles synthesised from biological } \\
\text { means are showing better antimicrobial activity } \\
\text { against the pathogenic bacteria }\end{array}$ \\
\hline
\end{tabular}




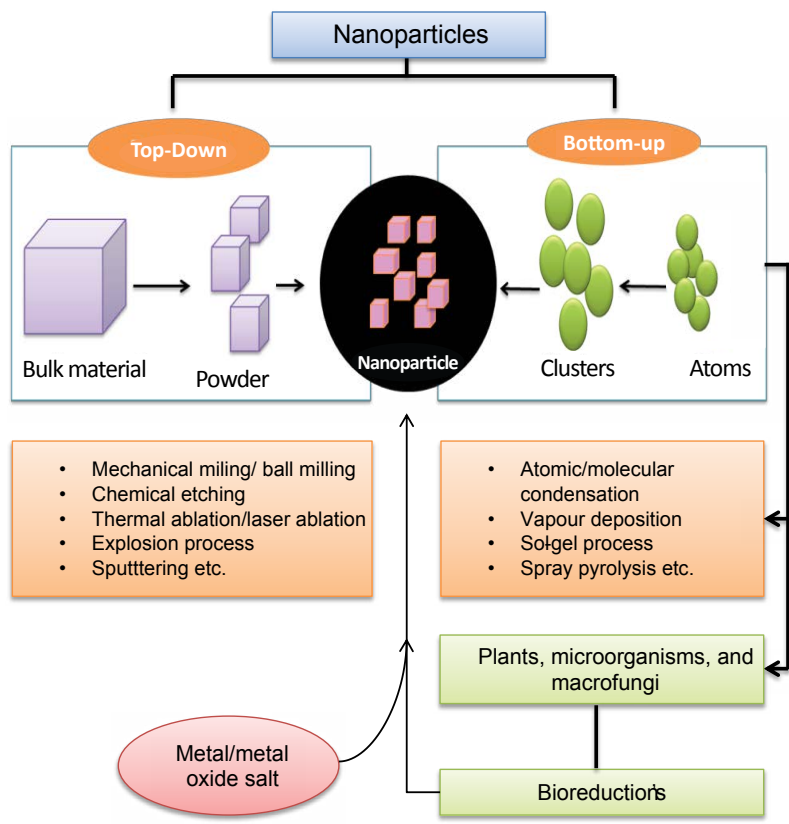

Fig. 1: Schematic representation of protocol employed for synthesis of nanoparticles ${ }^{[41]}$

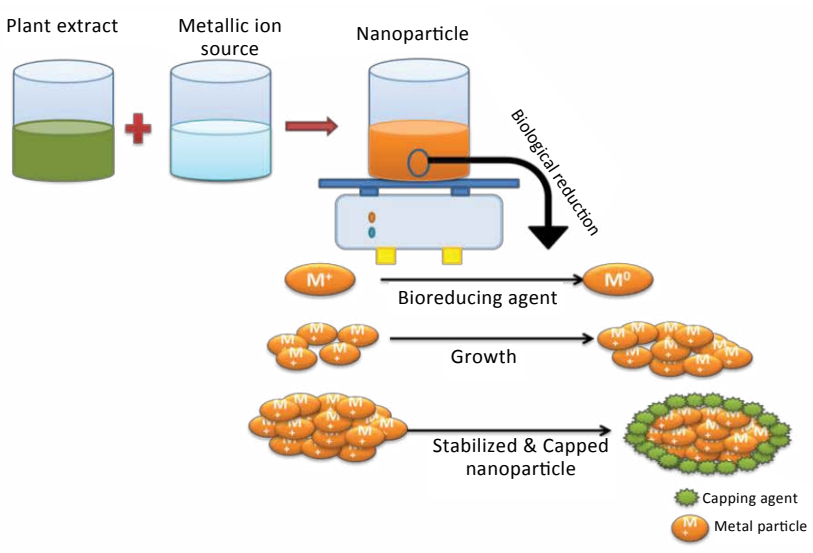

Fig. 2: Schematic representation of mechanism of biological synthesis of nanoparticles using plant extracts

synthesis of NPs more flexible, cost effective and it is the appropriate method for large scale production ${ }^{[26]}$. However, there is a drawback regarding bacterial nanofactories, firstly rate of synthesis is slow, available size and shapes are limited as compared to the conventional process of NPs synthesis. Hence, other biogenic procedures were investigated ${ }^{[27]}$.

\section{Fungus-mediated synthesis:}

Tolerance to bioaccumulation of metals, high binding ability and intercellular uptake makes fungi more efficient for biological synthesis of $\mathrm{NMs}^{[28]}$. The protocol for the synthesis of NPs is diverse: the enzymes secreted by fungus are efficient in silver ion reduction and induce metal NP production ${ }^{[29]}$. This method had been practiced in the beginning of $20^{\text {th }}$ century, using
Verticillium fungus for the production of AgNPs with diameter of $25 \pm 12 \mathrm{~nm}$ and spherical morphology ${ }^{[30,21]}$. In contrast to bacteria, NPs were formed below the fungal cell ${ }^{[31]}$ whereas, further investigations reported diverse morphologies within range from spherical, triangular to hexagonal ${ }^{[24]}$. The mechanisms of production of NPs hypothesized were, NPs are formed on the surface of mycelia instead of in solution. Due to electrostatic interaction between negatively charged carboxylate groups in enzymes (present in the cell wall of mycelia) and positively charged silver ions, the silver ions get adsorbed on surface of the fungal cell. Then the fungal enzyme reduces silver ions to silver nuclei ${ }^{[32]}$. Fungal synthesis of NPs offers advantages of carrying simpler bottom-up processing and easy handling of biomass.

The use of fungi in the synthesis of NPs is significant as the fugal cell secretes much higher amount of protein than bacteria that enhance the green production of NPs significantly, hence employed for large scale production of metal NPs. The NPs are produced extracellularly, therefore they are easy to purify and can be directly used in various applications ${ }^{[33]}$. The fungal mycelia mesh can tolerate flow pressure and other conditions in bioreactors as compared to plant material or bacteria $^{[34]}$. Most fungi have a high tolerance towards metals and have high wall-binding capability, as well as intracellular metal uptake capabilities. Therefore, natural nanofactories shifted from bacteria to fungi. For instance, the white rot fungus (Phaenerochaete chrysosporium) is nonpathogenic and this contributes to the large scale production $\mathrm{AgNPs}^{[34]}$. Apart from this, the fungal green synthesis offers rapid synthesis. Aspergillus fumigatus facilitate obtaining monodispersed AgNPs within matters of minutes ${ }^{[35]}$. A. flavus NPs combined with antibiotics enhance the antibacterial activity against the MDR bacteria ${ }^{[36]}$.

\section{Yeast-mediated green synthesis:}

Yeast was also examined for silver NP green synthesis $^{[37,38]}$. Some yeast strains (MKY3) are silver tolerant, initially, that were used for extracellular synthesis (Table 2) ${ }^{[39-45]}$. Recently, the biosynthesis of gold and AgNPs was investigated using the culture supernatant broth of the yeast Saccharomyces cerevisae and Candida guilliermondii. Metal NPs were formed after gold and silver ions came in contact with the culture supernatant broth ${ }^{[46]}$.

\section{Plant-mediated green synthesis:}

Green synthesis of NPs using plant extracts is advantageous as plants are easily accessible, clean, 
ecofriendly, safe to handle with the variety of highly active constituents that initiate the reduction of metal ions. The first approach toward plant-mediated synthesis of NPs was made with Alfalfa sprouts ${ }^{[47]}$. The root of Alfalfa can absorb silver from the surrounding growing medium (i.e. agar) and transfer it to the shoots in the same oxidation state. The translocated silver in the shoots is accumulated and arranged in such a way to form NPs. The production of NPs with plants gives faster rate of synthesis than bacteria and fungi. Geranium leaf extracts take about $9 \mathrm{~h}$ to reach $90 \%$ completion of NPs synthesis compared to 24 to $124 \mathrm{~h}$ required for other reactions stated previously ${ }^{[48]}$. Since then, the use of plant extracts in the synthesis of NPs escalated leading to a new era in green synthesis. Many investigators have demonstrated that the synthesis of NPs by plant extracts can be accomplished in the metal salt solution within a matter of minutes at room temperature, however, rate of synthesis depends on the nature of plant extracts (Table 3$)^{[49-60]}$. There are many other factors as type of metal salt used, concentration of plant extract, temperature and $\mathrm{pH}$, which affect the synthesis of $\mathrm{NPs}^{[26]}$.

Almost all parts of plants such as leaves, root, stem, latex, flowers and seeds have been employed for NP synthesis ${ }^{[61]}$. The biomolecules present in plants act as both reducing agents as well as capping agents that stabilize and govern the morphology of NPs (fig. 2). The leading biomolecules that involve as bio-reducing and capping agents of the metal NPs include, phenols, polysaccharides, flavones, terpenoids, alkaloids, proteins, amino acids, enzymes and alcoholic compounds. However, there are reports that chlorophyll pigments, quinol, methyl chavicol, linalool, eugenol, caffeine, ascorbic acid, theophylline and other vitamins also reduce the metallic salt to

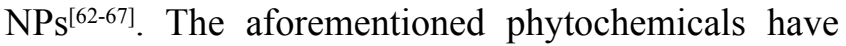
ability of reducing, stabilizing, capping and preventing accumulation of NPs. The hydroxyl and carboxyl group of phenolic compounds bind to the surface of metals ${ }^{[68]}$.

\section{ANTIMICROBIAL ACTIVITY OF NPs}

The ever escalating popularity and applications of NPs have impacted every possible field of research and scientific publication. The biogenically synthesized NPs also referred to as the green generation of NPs, the applications of which have resulted in sustainable advances in medicines, diagnosis and clinical applications ${ }^{[69-71]}$. The use of NPs is considered as a substitute for antibiotics with better efficacy with negligible side effects and for combating bacterial multidrug resistance. The green synthesized metal or metal oxide NPs have potent antibacterial, antifungal as well as antiparasitic activities ${ }^{[72-76]}$. The toxicity of metal NPs can be analyzed by various in vitro and in vivo studies. These studies reveal that NP-induced toxicity of metal-based NPs can affect the biological behaviour of the organ, tissue, cellular, subcellular and protein levels. The unique size of the NPs allows it to easily penetrate the cell and cause adverse effects (fig. 3). It is evident that metal-based NPs due to their biological and physiochemical properties are promising as antimicrobials and therapeutic agents (Table 4) ${ }^{[77-79]}$.

NPs, in particular have tremendous biocidal effects $^{[71,80]}$ and are therefore fascinating in a scientific field, especially for the production of new class of antimicrobials ${ }^{[81]}$. Though antimicrobial activity of AgNPs is of wide spectrum, the morphologically and metabolically different microorganisms appear to associate with multidimensional mechanisms of NPs to interact with microbes ${ }^{[82]}$. The structure, shape, and size of NPs and their mode of interaction with the surface of microbes offer a distinctive mechanisms of impairment and distinctive level of biocidal effects (fig. 3). The bactericidal efficacy of the NPs is influenced by concentration, size and shape of NPs and the studied microrganisims ${ }^{[83,84]}$. Small sized NPs seems to have a high tendency to penetrate deeper into the bacterial cell wall, and interact with the membrane leading to cell membrane damage. Certainly, the bactericidal excellence is much dominant in the smaller size of NPs than larger size with positive zeta potential. The NPs with zeta potential create electrostatic forces with the bacterial cell in contiguous. It is the potential difference between the dispersion medium and the stationary layer of fluid attached to the dispersed particle. As the bacterial cell wall has negative charge, promotes attraction between the two entities and hence penetration in to the bacterial membrane (fig. 3).

\section{MECHANISM OF ANTIMICROBIAL ACTIVITY OF NPs}

These include, direct uptake of NPs, indirect activity of NPs by production of reactive oxygen species (ROS) and impairment of cell wall/membrane.

\section{Direct uptake of NPs:}

As previously mentioned, antimicrobial properties of silver are remarkable; thus, it is probable that eluted 
TABLE 2: BIOLOGICAL ENTITIES USED IN SYNTHESIS OF METAL AND METAL OXIDE NPS WITH THEIR SIZE, SHAPE AND BRIEF BIOCIDAL ACTIVITY[84-90]

\begin{tabular}{|c|c|c|c|c|}
\hline Biogenic origin & NPs & Morphology & tBiocidal effects & Ref. \\
\hline \multicolumn{5}{|c|}{ Bacteria } \\
\hline $\begin{array}{l}\text { Pseudomonas stutzeri } \\
\text { AG259 }\end{array}$ & $\mathrm{Ag}$ & $200 \mathrm{~nm} /$ various shape & $\begin{array}{c}\text { Deal with the metal toxicity stress in the } \\
\text { environment }\end{array}$ & 23 \\
\hline $\begin{array}{l}\text { Proteus mirabilis } \\
\text { PTCC1710 }\end{array}$ & $\mathrm{Au}$ & $10-20 \mathrm{~nm} / \mathrm{spherical}$ & - & 25 \\
\hline Escherichia coli & $\mathrm{CdS}$ & 2-5 nm/spherical & $\begin{array}{l}\text { Used to synthesize green solar cell and } \\
\text { effective against } E \text {. coli (BW25113) }\end{array}$ & 83 \\
\hline Bacillus mycoides & $\mathrm{TiO} 2$ & $40-60 \mathrm{~nm} /$ spherical & Suppress aquatic biofilm growth & 84 \\
\hline Bacillus subtilis & $\mathrm{TiO} 2$ & $10-30 \mathrm{~nm} / \mathrm{spherical}$ & $\begin{array}{l}\text { Bioremediation without producing toxic } \\
\text { chemicals to the environment }\end{array}$ & 85 \\
\hline $\begin{array}{l}\text { Bacteria strains NS2 } \\
\text { and NS6 }\end{array}$ & $\mathrm{PbS}$ & $40-70 \mathrm{~nm}$ & $\begin{array}{l}\text { Bioremediation without producing toxic } \\
\text { chemicals to the environment }\end{array}$ & 86 \\
\hline Aeromonas hydrophila & $\mathrm{ZnO}$ & $57-72 \mathrm{~nm} / \mathrm{spherical}$ & $\begin{array}{c}\text { Exhibited antimicrobial activity against both } \\
\text { bacteria (Pseudomonas aeruginosa) and fungi } \\
\text { (Aspergillus flavus) }\end{array}$ & 53 \\
\hline \multicolumn{5}{|c|}{ Fungus } \\
\hline Aspergillus flavus & $\mathrm{TiO2}$ & $62-74 \mathrm{~nm} /$ oval & Effective against $S$. aureus & 87 \\
\hline Colletotrichum sp. & $\mathrm{Au}$ & $20-40 \mathrm{~nm} / \mathrm{spherical}$ & - & 88 \\
\hline Fusarium oxysporum & $\mathrm{Au}$ & $\begin{array}{l}\text { 20-40 } \mathrm{nm} / \mathrm{spherical}, \\
\text { triangle }\end{array}$ & $\begin{array}{l}\text { Antibacterial activity against burns bacterial } \\
\text { growth, E. coli, S. aureus }\end{array}$ & 16 \\
\hline Volvariella volvacea & $\begin{array}{l}\mathrm{Ag} \& \\
\mathrm{Au}\end{array}$ & $\begin{array}{l}\text { 20-150 nm/spherical/ } \\
\text { hexagonal }\end{array}$ & Shows antimicrobial activity & 89 \\
\hline Verticillium sp. & $\mathrm{Ag}$ & $25 \pm 12 \mathrm{~nm} / \mathrm{spherical}$ & Shows antimicrobial activity & 30 \\
\hline \multicolumn{5}{|c|}{ Yeast } \\
\hline MKY3 & $\mathrm{Ag}$ & 2-5/hexagonal & Activity against E.coli, $S$ aureus & 37 \\
\hline $\begin{array}{c}\text { Schizosacchromyces } \\
\text { pombe }\end{array}$ & $\mathrm{Cd}$ & 1-2/hexagonal & - & 90 \\
\hline
\end{tabular}

TABLE 3: PLANTS/PLANT PART-MEDIATED SYNTHESIS OF METAL AND METAL OXIDE NPS WITH THEIR SIZE, SHAPE AND BRIEF BIOCIDAL ACTIVITY[91-102]

\begin{tabular}{|c|c|c|c|c|}
\hline Biogenic origin & NPs & Morphology & Biocidal effects & Ref. \\
\hline Alfalfa & $\mathrm{Ag}$ & $2-20 \mathrm{~nm}$ & $\begin{array}{c}\text { Significantly increases root \& stem growth, } \\
\text { antibacterial }\end{array}$ & 39 \\
\hline Avena sativa & $\mathrm{Au}$ & $5-20 \mathrm{~nm} / \mathrm{rod}$ shaped & - & 18 \\
\hline Aloe vera & $\begin{array}{l}\mathrm{Au} \text { and } \\
\mathrm{Ag}\end{array}$ & $\begin{array}{l}50-350 \mathrm{~nm} / \mathrm{spherical} \\
\text { triangular }\end{array}$ & Bactericidal effects & 91,92 \\
\hline Camellia sinensis & $\mathrm{ZnO}$ & $\begin{array}{l}\text { 30-40 } \mathrm{nm} / \mathrm{spherical}, \\
\text { triangular }\end{array}$ & Strong antimicrobial effects & 93 \\
\hline Catharanthus roseus & $\mathrm{TiO}_{2}$ & $25-110 \mathrm{~nm} /$ irregular & $\begin{array}{l}\text { Effective again Hippobosca maculata (flies) and } \\
\text { Bovicola ovis (lice) }\end{array}$ & 94 \\
\hline Cassia auriculata & $\mathrm{ZnO}$ & - & $\begin{array}{l}\text { Used as an effective stabilizing, reducing agent for the } \\
\text { synthesis of NPs }\end{array}$ & 87 \\
\hline Cassia alata & $\mathrm{CuO}$ & $110-280 \mathrm{~nm} /$ spherical & Application in medicine & 50 \\
\hline Croton sparsiflorus & $\begin{array}{l}\text { Ag and } \\
\text { Pd }\end{array}$ & $22-52 \mathrm{~nm} /$ spherical & $\begin{array}{l}\text { Shows biocidal effects against S. aureus, } E \text { coli, } B . \\
\text { subtilis }\end{array}$ & 95 \\
\hline $\begin{array}{l}\text { Euphorbia } \\
\text { condylocarpa }\end{array}$ & $\mathrm{Fe}_{3} \mathrm{O}_{4}$ & Avg. $39 \mathrm{~nm}$ & Magnetically recoverable and recyclable catalyst & 96 \\
\hline Emblica officinalis & $\begin{array}{l}\mathrm{Ag} \text { and } \\
\mathrm{Au}\end{array}$ & $20-25 \mathrm{~nm} / \mathrm{spherical}$ & Antibacterial activity & 96 \\
\hline Euphorbia hirta & $\mathrm{Ag}$ & $50 \mathrm{~nm} /$ spherical & Biocidal activity & 97 \\
\hline Gloriosa superba & $\mathrm{CuO}$ & $5-10 \mathrm{~nm} /$ spherical & Effective against $S$. aureus and Klebsiella aerogenes & 98 \\
\hline Gum karaya & $\mathrm{CuO}$ & $\begin{array}{l}\text { Avg. } 4.8 \mathrm{~nm} \\
16-\end{array}$ & Antimicrobial activity against $E$. coli & 99 \\
\hline
\end{tabular}




\begin{tabular}{|c|c|c|c|}
\hline Geranium leaves & $\mathrm{Ag}$ & $\begin{array}{l}40 \mathrm{~nm} / \text { quasilinear } \\
\text { Superstructure }\end{array}$ & Antimicrobial activity \\
\hline Hibiscus rosa sinensis & $\begin{array}{c}\mathrm{Ag} \text { and } \\
\mathrm{Au}\end{array}$ & $14 \mathrm{~nm} /$ spherical & Strong antimicrobial activity \\
\hline Ipomoea aquatica & $\mathrm{Ag}$ & $\begin{array}{l}\text { Prism } 100-400 \mathrm{~nm} / \\
\text { spherical, cubic }\end{array}$ & - \\
\hline Jatropha curcas & $\mathrm{Ag}$ & $15-50 \mathrm{~nm} / \mathrm{spherical}$ & Biocidal effects \\
\hline Malva sylvestris & CuO & 5-30 nm/spherical & Effective against both Gram +ve and -ve bacteria \\
\hline Phyllanthus amarus & $\mathrm{CuO}$ & $20 \mathrm{~nm} / \mathrm{spherical}$ & Effective than rifampicin against $B$. subtilis \\
\hline
\end{tabular}
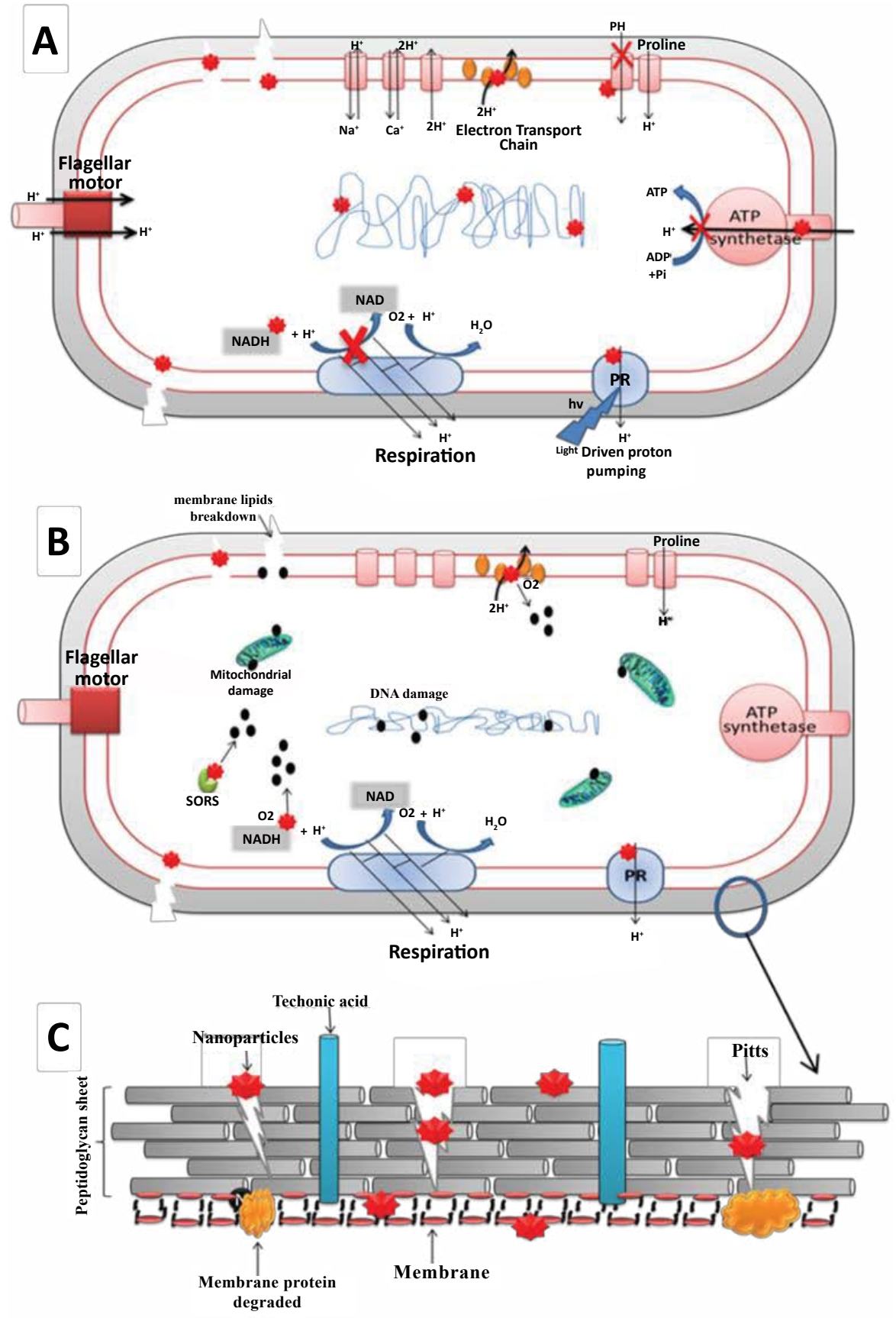

Fig. 3: Schematic representation of biocidal effects of nanoparticles on bacterial cell

(A) Cell uptake of Ag+ directly, Ag+ interacts with NADH dehydrogenase (respiratory chain enzyme), leads to uncoupling of respiration from ATP synthesis, Ag+ binds with transport protein, consequently proton leaks out, that collapse the proton motive force, efflux of intracellular phosphate; (B) nano activate ROS sault membrane lipids, abolishing the respiratory chain enzymes by direct interactions with thiol groups in these enzymes or the superoxide radical scavenging enzymes such as superoxide dismutases, mitochondrial and DNA damage occurs; (C) NPs leads to the pits formation in membrane that variates the permeability of the cell membrane due to release of lipopolysaccharides and proteins of membranes 
TABLE 4: COMMERCIALLY AVAILABLE NPS COMPOSED OF METAL/METAL OXIDE IONS USED FOR ANTIMICROBIAL ACTIVITY[103-105]

\begin{tabular}{|c|c|c|c|}
\hline $\begin{array}{l}\text { Metallic } \\
\text { constituents }\end{array}$ & Nanoparticles & Antibacterial activity & Reference \\
\hline \multirow[t]{2}{*}{ Pure metal } & Silver & $\begin{array}{c}\text { Pseudomonas aeruginosa, Staphylococcus aureus, Proteus } \\
\text { mirabilis, Escherichia coli, Klebsiella pneumoniae, and Bacillus } \\
\text { subtilis }\end{array}$ & $39,92,95$ \\
\hline & Gold & $\begin{array}{c}\text { Corynebacterium pseudotuberculosis, K. pneumoniae, S. typhi, P. } \\
\text { aeruginosa and E. coli }\end{array}$ & $18,92,96$ \\
\hline \multirow{5}{*}{ Single-metal oxide } & Aluminum oxide & E. coli DH5a, S. epidermidis, Scenedesmus sp. and Chlorella sp. & \\
\hline & Copper oxide & $\begin{array}{c}\text { E. coli, P. aeruginosa, K. pneumonia, Enterococcus faecalis, } \\
\text { Shigella flexneri, Salmonella typhimurium, P. vulgaris, and S. } \\
\text { aureus }\end{array}$ & $\begin{array}{l}55,100 \\
98,99\end{array}$ \\
\hline & Silicon oxide & E. coli, S. aureus, Bacillus, P. aeruginosa & 103 \\
\hline & Titanium oxide & $\begin{array}{l}\text { P. aeruginosa, E. coli, S. aureus, E. faecalis, } \\
\text { Pichia jadinii, Hippobosca maculata, Bovicola ovis }\end{array}$ & 94 \\
\hline & Zinc oxide & $\begin{array}{c}\text { E. coli, K. pneumoniae, S. dysenteriae, S. typhi, P. aeruginosa, B. } \\
\text { subtilis and S. aureus }\end{array}$ & 87,93 \\
\hline \multirow[t]{2}{*}{ Multi-metal oxide } & $\begin{array}{l}\text { Copper-substituted } \\
\text { cobalt ferrite }\end{array}$ & E. coli & 104 \\
\hline & Indium tin oxide & E. coli, S. aureus & 105 \\
\hline
\end{tabular}

ions from AgNPs are responsible for their antibacterial properties. Ag+ has high affinity to thiol groups in cysteine residue of respiratory and transport protein ${ }^{[85]}$. Therefore, at sub-micromolar concentrations cells take up $\mathrm{Ag}+$ directly, where it interacts with enzymes of the respiratory chain (NADH dehydrogenase) subsequently uncoupling of respiration from adenosine triphosphate (ATP) synthesis occurs. Ag+ also binds with transport protein consequently proton leaks out, stimulating collapse of the proton motive force ${ }^{[85,86]}$. Ag+ obstructs the uptake of phosphate and thus initiates the efflux of intracellular phosphate ${ }^{[87]}$. Further, it is reported that $\mathrm{Ag}+$ increases DNA mutation frequencies during polymerase chain reactions ${ }^{[88]}$. Bacterial cells exposed to millimolar $\mathrm{Ag}+$ doses endure morphological modifications such as DNA compression and localization in an electron-light region in the core of the cell, cytoplasm retrenchment, and degeneration of cell wall/membrane allowing leakage of intracellular contents ${ }^{[89]}$. Hence, physiological as well as morphological changes occur (fig. 3).

\section{The indirect activity of NPs through production of ROS:}

ROS are prospective by-products of the metabolic pathway of respiring organisms. Although antioxidant defence of the cell (glutathione/glutathione disulfide GSH/GSSG ratio) guards the cells to some extent from ROS, excess ROS production may produce oxidative stress $^{[8]}$ and can assault membrane lipids, consequently, leads to impairment of membrane and mitochondrial dysfunction and DNA damage ${ }^{[90]}$. Metals can act as catalysts and generate ROS in the presence of dissolved oxygen ${ }^{[1]}$. Therefore, AgNPs may catalyse the reaction with oxygen directing to release excess free radicals. In bacterial cells, $\mathrm{Ag}+$ are probably to induce the generation of ROS by abolishing the respiratory chain enzymes by direct interactions with thiol groups in these enzymes or the superoxide radical scavenging enzymes such as superoxide dismutases (fig. 3) ${ }^{[92]}$. The study by Kim et al. confers the presence of free radicals from AgNPs by means of spin resonance measurements ${ }^{[82]}$. They observed that the toxicity of AgNPs and silver nitrate was eliminated in the presence of an antioxidant, approving antimicrobial mechanisms of AgNPs against Staphylococcus aureus and Escherichia coli was interrelated to the formation of free radicals from the surface of AgNPs and consequent free radical persuade membrane damage.

\section{Impairment of cell wall:}

The unique size of the NPs allows it to easily penetrate inside the bacterial cell. Studies show that AgNPs adhere to and penetrate within E. coli cells at sizes much smaller than the original particles; moreover ${ }^{[93,94]}$ leads to the pits formation in membrane that variates the permeability of the cell membrane due to release of lipopolysaccharides and proteins of membranes ${ }^{[95]}$ (fig. 3). AgNPs degrade the peptidoglycan structure, and cell wall destruction proved by release of 
muramic acid, reported in $S$. aureus. Further, the gas chromatography-mass spectrometry (GC-MS) analysis (tandem) and muramic acid release validate the probable decomposition of glycan strands. These reports prove that AgNPs hinged with both the sides of peptidoglycan stratum of bacterial cell wall. Silver binds to beta-1,4- bonds of $\mathrm{N}$-acetylmuramic acid and $\mathrm{N}$-acetylglucosamine of peptidoglycan strands, and degrading their bond hence muramic acid set free ${ }^{[96]}$ (fig. 3).

The interaction between NPs and bacterial cells are due to electrostatic attraction between negative charges on the cell membranes and positive charge of NPs. However, this mechanism is inefficient to explain the adhesion and uptake of negatively charged AgNPs. It is also hypothesized that the preferential sites of uptake and interaction for AgNPs and membrane cells might be sulphur containing proteins in a similar way as silver interacts with thiol groups of respiratory chain proteins and transport proteins, interrupt their proper functioning ${ }^{[97]}$. Proteomic data demonstrate the accumulation of envelope protein precursors in E. coli cells after exposure to AgNPs. Energy from ATP and proton motive force is required in order to synthesize envelope proteins and to translocate it to the membrane; therefore cytoplasmic accumulation of protein precursors suggests degeneracy of proton motive force and depletion of intracellular levels of ATP.

\section{FACTORS AFFECTING ANTIMICROBIAL ACTIVITY OF NPs \\ THE}

\section{Concentration and size:}

The influence of size and concentration has been analyzed in many NPs. AgNPs with different sizes at a low concentration of $0.01 \mathrm{ppm}$ have been evaluated for activity $^{[82]}$. The smallest-sized spherical AgNPs were more efficient to kill and destroy bacteria as compared to larger spherical AgNPs. Due to the high surface to volume ratio, the smaller-sized NPs released more silver cations and thus, proved more effective to kill the bacteria as compared to larger-sized particles ${ }^{[98]}$.

\section{Chemical composition:}

The chemical composition is the base of the NPs that decides the variations in their activities. The NPs are recognized to produce $\mathrm{ROS}\left(\mathrm{TiO}_{2}, \mathrm{ZnO}_{2}\right.$ and $\left.\mathrm{SiO}_{2}\right)$ against Bacillus subtilis and E. coli. The biocidal activity of these compound was found in ascending order from $\mathrm{SiO}_{2}$ to $\mathrm{TiO}_{2}$ to $\mathrm{ZnO}$. The growth of B. subtilis was $90 \%$ inhibited by 10 ppm concentration of $\mathrm{ZnO} \mathrm{NPs}$, while growth of B. subtilis effectively inhibits to $90 \%$ by 1000 and 2000 ppm of $\mathrm{TiO}_{2}$ and $\mathrm{SiO}_{2}$, respectively. Whereas, the inhibition effect of NPs on E. coli was partially at $10 \mathrm{ppm}$ of ZnO NPs and $500 \mathrm{ppm}$ of both the NPs ${ }^{[99]}$. Further, it was specified that the bactericidal activity does not effects by the light or dark, suggesting growth inhibition involves mechanisms other than ROS production.

\section{The shape of NP:}

Studies conducted regarding the shape of the NPs have suggested that different shapes (spherical, elongated rod and truncated triangular) of AgNPs have different intensity of biocidal activity. The media supplemented with different shapes of NPs have different colonyforming unit count of E.coli. The activity of NPs seems to get stimulated by the morphology of NPs. The shape-dependent activity was determine in the term of facets, the spherical NPs primarily had 100 facets, rodshaped NPs had 111 facets on side surface and 100 on end, truncated triangular NPs with 111 facets on top basal planes. The facets 111 are of high atom density that favors antibacterial reactivity of $\mathrm{NPs}^{[100]}$.

\section{Target microorganisms:}

Many studies have reported that NPs showed greater biocidal activity against Gram-negative rod-shaped bacteria than Gram-positive cocci. The effect of AgNPs was analyzed using E. coli and $S$. aureus, where results showed significantly more activity against E. coli (MIC 3.3-3.6) than S. aureus (MIC more than $33 \mathrm{nM}$ ). The difference in results depicted difference in the cell wall organization, as the cell wall composition of Gram-positive bacteria ( $S$. aureus) consist of higher concentration of peptidogylcan ${ }^{[101]}$. However, Huang et al. revealed the activity of $\mathrm{ZnO}$ NPs against both Gram-positive ( $S$. aureus) and Gram-negative (E. coli) bacteria ${ }^{[99]}$. Whereas another study shows $\mathrm{ZnO}$ NPs higher activity against $S$. aureus than $E$. coli and P. aeruginosa ${ }^{[102]}$.

\section{Photo activation:}

The NPs of $\mathrm{TiO}_{2}$ showed activity against $E$. coli, and this activity significantly increases with UV radiations ${ }^{[20]}$. Further, it was reported that $\mathrm{TiO}_{2} \mathrm{NPs}$ has negligible activity i.e. it shows about $20 \%$ of growth inhibition of $S$. aureus without photoactivation. On the other hand, ZnONPs show escalating activity after photoactivation 
by UV radiation including visible light ${ }^{[103,104]}$. Lipovsky et al. has demonstrated that the photoactivation with blue light of these NPs enhances their activity by enhancing ROS production, with prominent effect in $\mathrm{ZnO} \mathrm{NPs}{ }^{[105]}$. Although, one can not be oblivious to the fact that bacterial incubation with NPs in dark condition has no effect on surviving of microorganisms ${ }^{[99]}$.

\section{Isolation and purification of NPs}

After centrifugation of metal NPs solution for $10 \mathrm{~min}$ at $10000 \mathrm{rpm}$, the NPs are settled at the bottom of the conical tube. The supernatant phase is removed and NPs is used to wash with $10 \mathrm{ml}$ water for three times. After the washing, the residue is transferred to freeze dryer.

Depending upon the preparation method used, various other impurities can be found in the NPs suspensions. Simple filtration will only remove polymer aggregates, while other impurities require more sophisticated procedure. The most common procedures are gel filtration, dialysis and ultracentrifugation. However, these methods are not entirely satisfactory because they are not capable of removing molecules with high molecular weights. This needs to development of cross flow filtration method in which the NPs suspension is filtered through membranes. The suspension is passed via several filtration cycles while filtrate containing components smaller than pores is discarded.

Recently, the use of microorganisms and plants for NP production has proved to be quite efficient. Simple bacteria to complex eukaryotes have been employed for the synthesis of NPs of desired size and shape. The green synthesis proved to be sustainable, eco-friendly, stable, non-toxic and cost effective. The production of green NPs can be equipped on large scale, with nontoxic plant easy disposed of. Most green synthesis approaches represent promising alternative approaches to antibiotics particularly dedicated to $\mathrm{Ag}$ and $\mathrm{Au}$ NPs. Other biogenically synthesized metals and its oxides NPs have commanding roles in human welfare. However, attention should be drifted toward the activity of NPs in combinations with antimicrobials of other class against MDR microorganisms. These can be used to address a number of challenges in the field of nanomedicine. But it must be remembered that they can also possibly cause adverse biological effects at the cellular and subcellular levels. Therefore, after the cytotoxicity and clinical studies, the NPs can find immense application as antimicrobials in the consumer and industrial products. Another aspect that is worth consideration is the factor that may influence the activity, shape, and size of NPs for enhanced production. Many studies illustrated the significant deviation in chemical composition of plant of same species when collected from habitats of different regions and thus lead to variation in the results.

\section{Acknowledgments:}

The authors thank the Head, Department of Botany, University of Allahabad for providing the research facilities and the UGC, New Delhi for financial support.

\section{Conflict of interest:}

All authors declare that they have no conflict of interests.

\section{REFERENCES}

1. Walker B, Barrett S, Polasky S, Galaz V, Folke C, Engstrom $\mathrm{G}$, et al. Environment. Looming global-scale failures and missing institutions. Science 2009;325:1345-46.

2. Cheng CJ, Tietjen GT, Saucier-Sawyer JK, Saltzman WM. A holistic approach to targeting disease with polymeric nanoparticles. Nat Rev Drug Discov 2015;14;239-47.

3. Bogunia-Kubik K, Sugisaka M. From molecular biology to nanotechnology and nanomedicine. BioSystems 2002;65:12338.

4. Senapati S. Biosynthesis and immobilization of nanoparticles and their applications [dissertation]. Pune: University of Pune; 2005.

5. Prashanth S, Menaka I, Muthezhilan R, Navin KS. Synthesis of plant-mediated silver nanoparticles using medicinal plant extract and evaluation of its antimicrobial activities. Int J Eng Sci Technol 2011;3:6235-50.

6. Ball P. Natural strategies for the molecular engineer. Nanotechnology 2002;13:15-28.

7. Taylor R, Walton DRM. The chemistry of fullerenes. Nature 1993;363:685-93.

8. Nel A, Xia T, Madler L, Li N. Toxic potential of materials at the nanolevel. Science 2006;311:622-27.

9. Gowramma B, Keerthi U, Mokula R, Rao DM. Biogenic silver nanoparticles production and characterization from native stain of Corynebacterium species and its antimicrobial activity. Biotech 2015;5:195-201.

10. Makarov VV, Love AJ, Sinitsyna OV, Makarova SS, Yaminsky IV, Taliansky ME, et al. Green nanotechnologies: Synthesis of metal nanoparticles using plants. Acta Naturae 2014;6:35-44.

11. Gokulakrishnan $\mathrm{R}$, Ravikumar $\mathrm{S}$, Raj JA. In vitro antibacterial potential of metal oxide nanoparticles against antibiotic resistant bacteria pathogens. Asian Pac J Trop Dis 2012;2:411-13.

12. Nasrollahi A, Paurshamsian KH, Mansourkiaee P. Antifungal activity of silver nanoparticles on some of fungi. Int $\mathrm{J}$ Nano Dimens 2011;1:233-9.

13. Stoimenov PK, Klinger RL, Marchin GL, Klabunde KJ. Metal oxide nanoparticles as bactericidal agents. Langmuir 2002;18:6679-86.

14. Diva B, Lingappa K, Dayanand A. Antibacterial activity of 
nano gold particles synthesized by Bacillus sp. J Ecobiotechnol 2012;4:43-5.

15. Singh A, Singh NB, Hussain I, Singh H, Singh SC. Plantnanoparticle interaction: An approach to improve agricultural practices and plant productivity. Int $\mathrm{J}$ Pharm Sci Invent 2015;4:25-40.

16. Gudikandula K, Maringanti SC. Synthesis of silver nanoparticles by chemical and biological methods and their antimicrobial properties. J Exp Nanosci 2016;11(9):714-21.

17. Thakkar KN, Mhatre SS, Parikh RY. Biological synthesis of metallic nanoparticles. Nanomedicine 2010;6:257-62.

18. Korbekandi H, Iravani S, Abbasi S. Production of nanoparticles using organisims. Crit Rev Biotechnol 2009;29:279-306.

19. Dura'n N, Marcato PD, De S, Gabriel IH, Alves OL, Esposito E. Mechanistic aspects of biosynthesis of silver nanoparticles by several Fusarium oxysporum strains. J Biomed Nanotechnol 2007;3:203-8.

20. Huang J, Li Q, Sun D, Lu Y, Su Y, Yang X, et al. Biosynthesis of silver and gold Nanoparticles by novels sundried Cinnamomum camphora leaf. Nanotechnology 2007;18:104.

21. Ahmad A, Mukherjee P, Senapati S. Extracellular biosynthesis of silver nanoparticles using the fungus Fusarium oxysporum. Colloids Surf B Biointerfaces 2003;28:313-8.

22. Pooley FD. Bacteria accumulate silver during leaching of sulphide ore minerals. Nature 1982;296:642-43.

23. Klaus T, Joerger R, Olsson E, Granqvist CG. Silver- based crystalline nanoparticles, microbially fabricated. Proc Natl Acad Sci U S A 1999;96:13611-14.

24. Al-Harbi MS, El-Deeb BA, Mostafa N, Amer SAM. Extracellular biosynthesis of AgNPs by the bacterium Proteus mirabilis and its toxic effect on some aspects of animal physiology. Adv Nanoparticles 2014;3:83-91.

25. Samadi N, Golkaran D, Eslamifar A, Jamalifar H, Fazeli MR, Mohseni FA. Intra/extracellular biosynthesis of silver nanoparticles by an autochthonous strain of Proteus mirabilis isolated from photographic waste. J Biomed Nanotechnol 2009;5:247-53.

26. Kharissova OV, Dias HVR, Kharisov BI, Perez BO, Perez VMJ. The greener synthesis of nanoparticles. Trends Biotechnol 2013;31:240-8.

27. Murali S, Absar A, Khan IM, Rajiv K. Biosynthesis of metal nanoparticles using fungi and actinomycetes. Curr Sci 2003;85:162-70.

28. Mandal D, Bolander ME, Mukhopadhyay D, Sarkar G, Mukherjee P. The use of microorganisms for the formation of metal nanoparticles and their application. Appl Microbiol Biotechnol 2006;69:485-92.

29. Khan SA, Ahmad A. Fungus mediated synthesis of biomedically important cerium oxide nanoparticles. Mater Res Bull 2013;48:4134-8.

30. Mukherjee P, Ahmad A, Mandal D. Fungus-mediated synthesis of silver nanoparticles and their immobilization in the mycelia matrix: a novel biological approach to nanoparticle synthesis. Nano Letters 2001;1:515-9(a).

31. Mukherjee P, Ahmad A, Mandal D, Senapati S, Sainkar SR, Khan MI, et al. Bioreduction of $\mathrm{AuCl}^{-}$ions by the fungus, Verticillium sp. and surface trapping of the gold nanoparticles formed. Angew Chem Int Ed Engl 2001;40:3585-8(b).

32. Rauwel P, Küünal S, Ferdov S, Rauwel E. A review on the green synthesis of silver nanoparticles and their morphologies studied via TEM. Adv Mater Sci Eng 2015;2015:682749.

33. Vigneshwaran N, Kathe AA, Varadarajan PV, Nachane RP,
Balasubramanya RH. Biomimetics of silver nanoparticles by white rot fungus, Phaenerochaete chrysosporium. Colloids Surf B Biointerfaces 2006;53:55-9.

34. Narayanan KB, Sakthivel N. Biological synthesis of metal nanoparticles by microbes. Adv Colloid Interface Sci. 2010;156:113.

35. Naqvi SZH, Kiran U, Ali MI. Combined efficacy of biologically synthesized silver nanoparticles and different antibiotics against multidrug-resistant bacteria. Int $\mathrm{J}$ Nanomedicine 2013;8:3187-95.

36. Mourato A, Gadanho M, Lino AR. Tenreiro R. Biosynthesis of crystalline silver and gold nanoparticles by extremophilic yeasts. Bioinorg Chem Appl 2011;546074:8.

37. Apte M, Sambre D, Gaikawad S. Psychrotrophic yeast Yarrowia lipolytica NCYC 789 mediates the synthesis of antimicrobial silver nanoparticles via cell-associated melanin. AMB Express 2013;3:32.

38. Kowshik M, Ashtaputre S, Kharrazi S. Extracellular synthesis of silver nanoparticles by a silver-tolerant yeast strain MKY3. Nanotechnology 2003;14:95-100.

39. Aenishanslins NAO, Saona LA, Duran-Toro VM, Monras JP, Bravo DM, Donoso JMP. Use of titanium dioxide nanoparticles biosynthesized by Bacillus mycoides in quantum dot sensitized solar cells. Microb Cell Fact 2014;13:90.

40. Elumalai EK, Prasad TNVKV, Hemachandran J, Therasa SV, Thirumalai T, David E. Extracellular synthesis of silver nanoparticles using leaves of Euphorbia hirta and their antibacterial activities. J Pharm Sci Res 2010;2:549-54.

41. Vellora V, Padil T, Cernik M. Green synthesis of copper oxide nanoparticles using gum karaya as a biotemplate and their antibacterial application. Int J Nanomedicine 2013;8:889-98.

42. Ramimoghadam D, Bagheri S, Bee S, Hamid A. Biotemplated synthesis of anatase titanium dioxide nanoparticles via lignocellulosic waste material. Bio Med Res Int 2014; 7:205636.

43. Armendariz V, Herrera I, Peralta-Videa JR, Jose-Yacaman M, Troiani H, Santiago P, et al. Size controlled gold nanoparticle formation by Avena sativa biomass: use of plants in nanobiotechnology. J Nanopart Res 2004;6:377-82.

44. Dhandapani P, Maruthamuthu S, Rajagopal G. Biomediated synthesis of $\mathrm{TiO} 2$ nanoparticles and its photocatalytic effect on aquatic biofilm. J Photochem Photobiol B 2012;110:43-9.

45. Rajakumar G, Rahuman AA, Roopan SM, Khannac VG, Elango G, Kamaraj C. Fungus mediated biosynthesis and characterization of $\mathrm{TiO} 2$ nanoparticles and their activity against pathogenic bacteria. Spectrochim Acta Part A 2012;9:123-9.

46. Gardea TJL, Gomez E, Peralta VJR, Parsons JG, Troiani H, Jose YM. Alfalfa sprouts: a natural source for the synthesis of silver nanoparticles. Langmuir 2003;19:1357-61.

47. Shankar SS, Ahmad A, Sastry M. Geranium leaf assisted biosynthesis of silver nanoparticles. Biotechnol Prog 2003;19:1627-31.

48. Mittal AK, Chisti Y, Banerjee UC. Synthesis of metallic nanoparticles using plant extracts. Biotechnol Adv 2013;31:346-56.

49. Ramesh P, Rajendran A, Shisundaram MM. Green synthesis of zinc oxide nanoparticles using flower extract Cassia. J Nanosci Nanotechnol 2014;2:41-5.

50. Ankamwar B, Chaudhary M, Mural S. Gold nanotriangles biologically synthesized using tamarind leaf extract and potential application in vapour sensing. Synth React Inorg Metel-Org Nano-Met Chem 2005;35:19-26. 
51. Shankar SS, Rai A. Ankamwar B, Singh A, Ahmad A, Sastry M. Biological synthesis of triangular gold nanoprisms. Nat Mater 2004;3:482-8.

52. Senthilkumar SR, Sivakumar T. Green tea (Camellia sinensis) mediated synthesis of zinc oxide $(\mathrm{ZnO})$ nanoparticles and studies on their antimicrobial activities. Int J Pharm Pharm Sci 2014;6:461-65.

53. Chaloupka K, Malam Y, Seifalian AM. Nanosilver as a new generation nanoproduct in biomedical applications. Trends Biotechnol 2010;28:580-88.

54. Nasrollahzadeha M, Sajadib SM, Maham M. Green synthesis of palladium nanoparticles using Hippophae rhamnoides Linn leaf extract and their catalytic activity for the Suzuki-Miyaura coupling in water. J Mol Catal A Chem 2015;396:297-303.

55. Kathiravan V, Ravi S, Kumar SA, Velmurugan S, Elumalai K, Khatiwada CP. Green synthesis of silver nanoparticles using Croton sparsiflorusmorong leaf extract and their antibacterial and antifungal activities. Spectrochim Acta A Mol Biomol Spectrosc 2015;139:200-5.

56. Philip D. Green synthesis of gold and silver nanoparticle using Hibiscus rosa sinensis. Physica E Low Dimens Syst Nanostruct 2010;42:1417-24.

57. Sanghi R, Verma P. A facile green extracellular biosynthesis of CdS nanoparticles by immobilized fungus. Chem Eng J 2009;155:886-91.

58. Roy N, Barik A. Green synthesis of silver nanoparticle from the unexploited weed resources. Int J Nanotechnol Appl 2010;4:95-101.

59. Chandran SP, Chaudhary M, Pasricha R, Ahmad A, Sastry M. Synthesis of gold nanotriangles and silver nanoparticles using Aloe vera plant extract. Biotechnol Prog 2006;22:577-83.

60. Velayutham K, Rahuman AA, Rajakumar G, Santhoshkumar T, Marimuthu S, Jayaseelan C, et al. Evaluation of Catharanthus roseus leaf extract-mediated biosynthesis of titanium dioxide nanoparticles against Hippobos camaculata and Bovicola ovis. Parasitol Res 2012;111:2329-37.

61. Sharma VK, Yngard RA, Lin Y. Silver nanoparticles: Green synthesis and their antimicrobial activities. Adv Colloid Interface Sci 2009;145:83-96.

62. Kesharwani J, Yoon KY, Hwang J, Rai M. Phyto-fabrication of silver nanoparticles by leaf extract of Datura metel: hypothetical mechanism involved in synthesis $\mathrm{J}$ Bionanosci 2009;3:139-44.

63. Kumar MS, Sneha K, Won SW, Cho CW, Kim S, Yun YS. Cinnamon zeylanicum bark extract and powder mediated green synthesis of nano-crystalline silver particles and its bactericidal activity. Colloids Surf B Biointerfaces 2009;73:332-38.

64. Mallikarjuna K, Narasimha G, Dilip GR. Green synthesis of silver nanoparticles using Ocimum leaf extract and their characterization. Dig J Nanomater Biostruct 2011;6:181-6.

65. Kasthuri J, Kathiravan K, Rajendiran N, Phyllanthin-assisted biosynthesis of silver and gold nanoparticles: a novel biological approach. J Nanopart Res 2009;11:1075-85.

66. Bindhu MR, Umadevi M. Synthesis of monodispersed silver nanoparticles using Hibiscus cannabinus leaf extract and its antimicrobial activity. Spectrochim Acta A Mol Biomol Spectrosc 2013;101:184-90.

67. Ahmad N, Sharma S, Alam MK. Rapid synthesis of silver nanoparticles using dried medicinal plant of basil. Colloids Surf B Biointerfaces 2010;81:81-6.

68. Slawson RMM, Dyke IV, Lee H, Trevors JT. Germanium and silver resistance, accumulation, and toxicity in microorganisms. Plasmid 1992;27:72-9.

69. Kargara H, Ghasemi F, Darroudid M. Bioorganic polymer based synthesis of cerium oxide nanoparticles and their cell viability assays. Ceram Int 2015;1.41:1589-94.

70. Jana S, Pal T. Synthesis, characterization and catalytic application of silver nanoshell coated functionalized polystyrene beads. J Nanosci Nanotechnol 2015;7:2151-6.

71. Stiufiuc R, Iacovita C, Lucaciu CM, Stiufiuc G, Dutu AG, Braescu C, et al. SERS- active silver colloids prepared by reduction of silver nitrate with short-chain polyethylene glycol. Nanoscale Res Lett 2013;8:47.

72. Acharyulu NPS, Dubey RS, Swaminadham V, Kalyani RL, Kollu P, Pammi SVN. Green synthesis of $\mathrm{CuO}$ nanoparticles using Phyllanthus amarus leaf extract and their antibacterial activity against multidrug resistance bacteria. IJERT 2014;3:639-41.

73. Gopinath K, Shanmugam VK, Gowri S, Senthilkumar V, Kumaresan S, Arumugam A. Antibacterial activity of ruthenium nanoparticles synthesized using Gloriosa superba L. leaf extract. J Nanostruct Chem 2014;4:83.

74. Naika HR, Lingaraju K, Manjunath K, Kumar D, Nagaraju G, Suresh $\mathrm{D}$, et al. Green synthesis of $\mathrm{CuO}$ nanoparticles using Gloriosa superba L. extract and their antibacterial activity. J Taibah Univ Sci 2015;9:7-12.

75. Awwad AM, Albiss BA, Salem NM. Antibacterial activity of synthesized copper oxide nanoparticles using Malva sylvestris leaf extract. SMU Med J 2015;2:91-101.

76. Hussain I, Singh NB, Singh A, Singh H, Singh SC. Green synthesis of nanoparticles and its potential application. Biotechnol Lett 2015;15:2026-7.

77. Camporotondia DE, Fogliaa ML, Alvareza GS, Meberta AM, Diaza LE, Desimonea CTMF. Antimicrobial properties of silica modified nanoparticles. In: Méndez-Vilas A, editor. Microbial pathogens and strategies for combating them: science, technology and education. Badajoz, Spain: Formatex; 2013. p. 283-90.

78. Samavati AF. Ismail 2017. Antibacterial properties of coppersubstituted cobalt ferrite nanoparticles synthesized by coprecipitation method. Particuology 2016;30:158-63.

79. Kamaraj P, Vennila R, Arthanareeswari M, Devikala S. Biological activities of tin oxide nanoparticles Synthesized using plant extract. World J Pharm Pharm Sci 2014;3:382-88.

80. Jayaseelan C, Rahuman AA, Kirthi AV, Marimuthu S, Santhoshkumar T, Bagavan A, et al. Novel microbial route to synthesize $\mathrm{ZnO}$ nanoparticles using Aeromonas hydrophily and their activity against pathogenic bacteria and fungi. Spectrochim Acta A Mol Biomol Spectrosc 2012;90:78-84.

81. Periasamy S, Joo HS, Duong AC, Bach TH, Tan VY, Chatterjee SS, et al. How Staphylococcus aureus biofilms develop their characteristic structure. Proc Natl Acad Sci U S A 2012;109:1281-6.

82. Kim JS, Kuk E, Yu KN, Kim JH, Park SJ, Lee HJ, et al. Antimicrobial effects of silver Nanoparticles. Nanomedicine 2007;3:95-101.

83. Mirzajani F, Ghassempour A, Aliahmadi A, Esmaeili MA. Antibacterial effect of silver nanoparticles on Staphylococcus aureus. Res Microbiol 2011;162:542-9. 
84. Liu HL, Dai SA, Fu KY, Hsu SH. Antibacterial properties of silver Nanoparticles in three different sizes and their nanocomposites with a new waterborne polyurethane. Int J Nanomedicine 2010;5:1017-28.

85. Holt K, Bard A. Interaction of silver (I) ions with the respiratory chain of Escherichia coli: an electrochemical and scanning electrochemical microscopy study of the antimicrobial mechanism of micromolar Ag. Biochemistry 2005;44:13214-23.

86. Lok C, Ho C, Chen R, He Q, Yu W, Sun H, et al. Proteomic analysis of the mode of antibacterial action of silver nanoparticles. J Proteome Res 2006;5:916-24.

87. Schreurs W, Rosenberg H. Effect of silver ions on transport and retention of phosphate by Escherichia coli. J Bacteriol 1982;152:7-13.

88. Yang W, Shen C, Ji Q, An H, Wang J, Liu Q, et al. Food storage material silver nanoparticles interfere with DNA replication fidelity and bind with DNA. Nanotechnology 2009;20:085102.

89. Jung WK, Koo HC, Kim KW, Shin S, Kim SH, Park YH. Antibacterial activity and mechanism of action of the silver ion in Staphylococcus aureus and Escherichia coli. Appl Environ Microbiol 2008;74:2171-78.

90. Dos Santos CA, Seckler MM, Ingle AP, Gupta I, Galdiero S, Galdiero M, et al. Silver nanoparticles: Therapeutic uses, toxicity, and safety issues. J Pharm Sci 2014;103:1931-44.

91. Rai M, Deshmukh SD, Ingle AP, Gupta IR, Galdiero M, Galdiero S. Metal nanoparticles: The protective nanoshield against virus infection. Crit Rev Microbiol 2014;1-11.

92. Park HJ, Kim YJ, Kim J, Lee JH, Hahn SJ, Gu MB, et al. Silver ion mediated reactive oxygen species generation affecting bactericidal activity. Water Res 2009;43:1027-32.

93. Choi O, Deng K, Kim N, Ross L, Surampalli R, Hu Z. The inhibitory effects of silver nanoparticles, silver ions, and silver chloride colloids on microbial growth. Water Res 2008;42:3066-74.

94. Raffi M, Hussain F, Bhatti T, Akhter J, Hameed A, Hasan M. Antibacterial characterization of silver nanoparticles against E. coli ATCC-15224. J Mater SciTechnol 2008;24:192-6.
95. Adams LK, Lyon DY, Alvarez PJ. Comparative eco-toxicity of nanoscale $\mathrm{TiO} 2, \mathrm{SiO} 2$ and $\mathrm{ZnO}$ water suspensions. Water Res 2006;40:3527-32.

96. Pal S, Tak YK, Song JM. Does the antibacterial activity of silver Nanoparticles depend on the shape of nanoparticle? A study of the Gram-negative bacterium Escherichia coli. Appl Environ Microbiol 2007:73:1712-20.

97. Morones J, Elechiguerra J, Camacho A, Holt K, Kouri J, Ramirez J, et al. The bactericidal effect of silver nanoparticles. Nanotechnology 2005;16:2346-53.

98. Torres LA, Gmez-Quintero TJR, Padron GH, Santana FB, Hernandez JF, Castano VM. Silver nanoprisms and nanospheres for prosthetic biomaterials. San Francisco, California: IADR/ AADR/CADR General Session and Exhibition; 2013.

99. Huang X, Zheng D, Yan G, Yin X, Liao Y, Kang Y, et al. Toxicological effect of $\mathrm{ZnO}$ Nanoparticles based on bacteria. Langmuir 2008;24:4140-44.

100. Liu P, Duan W, Wang Q, Li X. The damage of outer membrane of Escherichia coli in the presence of TiO2 combined with UV light. Colloids Surf B Biointerfaces 2010;78:171-76.

101. Wang Z, Lee YH, Wu B, Horst A, Kang Y, Tang YJ, et al. Antimicrobial activities of aerosolized transition metal oxide Nanoparticles. Chemosphere 2010;80:525-28.

102. Mao RYC, Gao X, Burt JL, Belcher AM, Georgiou G, Lverson Sweeney BL. Bacterial biosynthesis of cadmium sulfide nanocrystals. Chem Biol 2004;11:1553-59.

103. Shankar SS, Ahmad AR, Pasricha, Sastry M. Bioreduction of chloroaurate ions by geranium leaves and its endophytic fungus yields gold nanoparticles of different shapes. J Mater Chem 2003;13:1822-26.

104. Philip D. Biosynthesis of $\mathrm{Au}, \mathrm{Ag}$ and $\mathrm{Au}-\mathrm{Ag}$ nanoparticles using edible mushroom extract. Spectrochim Acta A 2009;73:374-81.

105. Lipovsky A, Gesanken A, Nitzan Y, Lubart R. Enhanced inactivation of Bacteria by metal-oxide nanoparticles combined with visible light irradiation. Lasers Surg Med 2011;43:236-40. 